\title{
ORCHESTRATOR TYPES, ROLES AND CAPABILITIES \\ - A FRAMEWORK FOR INNOVATION NETWORKS
}

\begin{abstract}
In this study, attention is turned to those actors who orchestrate innovation networks; their types, roles and capabilities. We assert that the type of orchestrator and what they (can) do are related. Our starting point is that while orchestration in general comprises a variety of important activities, ranging from ensuring knowledge mobility to coordination, not all of these are accomplished by the same means or are equally emphasized at all times. A conceptual review of existing literature and the related qualitative comparative analysis suggest that orchestrators take different roles by focusing on specific sets of activities at certain times and conducting them in different ways. This implies mastering specific capabilities. Furthermore, sometimes circumstances push orchestrators to adopt roles that are unnatural to them. In those cases, capabilities of a different nature become relevant. Following from this line of thinking, our findings indicate three types of capabilities. First, operational role-implementation capabilities determine the ease and success of executing role-specific activities. Second, we further suggest that role-switching capabilities allow the orchestrator to move between the roles that it can naturally adopt. A third type of capability, role-augmentation, is needed to adopt roles beyond natural limitations related to orchestrator type. The resulting conceptual framework aims to combine the scattered existing literature and provide conceptual tools for future research.
\end{abstract}

Keywords: Orchestration, capabilities, activities, roles, orchestrator types, innovation networks 


\section{INTRODUCTION}

\subsection{Background}

Innovation activities increasingly take place in the interaction between organizations in different networks and ecosystems (e.g., Dhanaraj \& Parkhe, 2006; Laperche, Munier \& Hamdouch, 2008; Reypens, Lievens \& Blazevic, 2016). Accordingly, such networks have attracted a notable amount of managerial and academic interest. However, one of the central aspects that remains inconclusive is management in and of innovation networks, especially considering the variety among actors that pursue value creation and its capture.

Managing - or orchestrating (Dhanaraj \& Parkhe, 2006) - innovation networks is not a new issue, but discussion on the phenomenon has been on the rise in recent years (Gardet \& Mothe, 2011; McDermott, Mudambi \& Parente, 2013). Insights into various aspects of orchestration can be found in extant literature. Some studies have produced a broad general understanding of orchestration. For example, Dhanaraj and Parkhe (2006) describe innovation network orchestration in terms of taking deliberate, purposeful actions for initiating and managing innovation processes. Some studies have considered different types of networks from the point of view of management and orchestration (e.g., Möller \& Rajala, 2007; Hurmelinna-Laukkanen, Möller \& Nätti, 2011). Other studies have offered more detailed reports on orchestration in specific innovation networks (e.g., Dollet \& Matalobos, 2010; Leten et al., 2013; Dyer \& Nobeoka, 2000). Likewise, in the network literature there is some discussion on the different roles of orchestrators (Hinterhuber, 2002; Czakon \& Klimas, 2014), the different types of orchestrators (Roijakkers et al., 2013; Sabatier, Mangematin \& Rousselle, 2010) and the capabilities needed in network orchestration (Mitrega et al., 2012; 
Sullivan \& Weerawardena, 2006). However, it seems that orchestration-related literature, while broad, is also quite fragmented.

Our aim is to bring together, under a coherent conceptual framework, core aspects related to innovation network orchestrators, as well as the roles they take and their related capabilities. The existing literature acknowledges that different activities and capabilities are needed in different networks (e.g., Möller \& Svahn, 2003). Likewise, the importance of a leading organization ("hub," "focal firm" or "focal organization") in the success of networks has been recognized on numerous occasions (e.g., Belussi \& Arcangeli, 1998; Czakon \& Klimas, 2014; Convay \& Steward, 1998). However, these two notions do not seem to meet in existing studies. As Verhoeven \& Maritz $(2012,4)$ note, "It appears that orchestrators in innovation networks are under-researched [...]. There is some empirical support [...], but little theory development." Heidenreich, Landsperger and Spieth (2014) likewise argue that there is a lack of research on the orchestrator's roles, functions and influence in networks (see also Paquin \& Howard-Grenville, 2013, and Pittaway et al., 2004). Relatedly, despite their evident importance, orchestrator capabilities have remained largely untapped (see also Mitrega et al., 2012, on this type of challenge with regard to networking capabilities). The challenge is that innovation network types are not necessarily directly linked to the types of orchestrators. A fuzzy innovation network may well be led by a university, a start-up or an established company, for example. Therefore, the network type examined in earlier research may not be the only relevant factor in understanding issues related to orchestration activities' success or failure. It is equally important to acknowledge the capabilities and limitations of orchestrators in the networks.

In this study, we address the aforementioned issues through the following question: How does the orchestrator type relate to the roles emerging in innovation networks, and how do orchestrator capabilities maintain or change this relationship? In particular, we are 
interested in finding out if there are specific types of capabilities that allow orchestrators to take on and succeed in varying roles. Deviating from most existing research, we do not concentrate so much on the actual actions of the orchestrators (see e.g., Dhanaraj \& Parkhe, 2006), or the factors that allow some actors to emerge as leading organizations (see Czakon \& Klimas, 2014). Rather, we approach the topic from the point of view of intrinsic types of orchestrators, the roles they take, and the capabilities held by and required from these actors. This also has an effect on our methodological choices and the structure of our paper.

\subsection{Research design}

In the search for answers to our research question, we build upon the logic of a conceptual review (Kennedy, 2007; Baumeister \& Leary, 1997) and qualitative comparative analysis. We believe that such an approach is needed to uncover patterns of invariance on the one hand, and to also acknowledge any relevant deviation from these patterns (see Ragin, 1987) on the other hand. The flexibility of the conceptual approach allows us to combine a variety of source materials and concepts, and address also such issues that are present more implicitly in the existing discussion (see Kennedy, 2007; Ragin, 1987). Such an open approach is promoted, for example, by Shepherd and Suddaby (2017). In our approach, there is a lot common with the bricolage approach (e.g., Shepherd and Suddaby, 2017; see also Boxenbaum and Rouleau, 2011) that is based on researchers using their judgement in selecting and combining diverse enough concepts from existing discussions in novel ways.

While the reference materials used in this study were mainly sought and selected based on a keyword search - for the emergence of the innovation network and orchestration concepts in particular - we also extended our search to the broader network literature, taking into account what has been written about network management and network coordination, for example. The search for materials subsequently involved keywords such as '(innovation) 
network orchestration,' 'network management,' 'network coordination' and 'network roles.' For the capability discussion, we first searched for indications of capabilities in the network literature (especially regarding network orchestration and relationship management, for example). Then we examined the strategic management literature selectively in order to finalize the conceptual framing. In both of these cases we started from esteemed journals ${ }^{1}$, but we also allowed the inclusion of other sources if we found their insights to be notably relevant (see e.g., Pentland et al., 2011, for this type of research approach).

Finally, we examined prior qualitative studies in order to achieve more depth in the theorizing and conceptualization and to gain latitude with regard to methodological aspects. Practical case descriptions identified during our literature search, with a subsequent analysis of the content of said descriptions both individually and jointly, informed us how orchestration is conducted in practice in varying settings (see Ragin, 1987). While the authors of the case studies have approached the cases as a whole, we considered the different parts in relation to each other and disentangled these cases. This allowed us to give meaning not only to the presence of specific concepts and factors, but also to the absence of them.

Following from the chosen approach, the remainder of our study is structured as follows: We report our findings from our review of the existing literature and identify different types of orchestrators. We then discuss the activities that orchestrators carry out. Since our focus is on the orchestrator roles rather than activities as such, we describe how these activities are emphasized and conducted differently in different roles that orchestrators undertake. We explain the importance of the relationship between orchestrator types and roles, and finally turn our attention to orchestrator capabilities. We outline capabilities that are relevant for carrying out orchestration activities within orchestrator roles, for moving between roles within the frames that are natural to the orchestrator type in question, and for extending the role portfolio beyond the natural limitations. Throughout, we introduce illustrative 
examples to accompany the more theoretical discussion. Finally, we present some concluding remarks to our study.

\section{ELEMENTS OF INNOVATION NETWORK ORCHESTRATION}

The organization of networks and the organization in networks where both collective and individual (even opportunistic) goals are present is always challenging (Hernandez, Sanders $\&$ Tuschke, 2015). The success of innovation networks therefore calls for careful direction and coordination; it calls for orchestration. In line with Verhoeven \& Maritz (2012, 5), innovation network orchestration can be seen as "the set of deliberate, purposeful actions undertaken by a focal organization for initiating and managing innovation processes in order to exploit marketplace opportunities, enabling the focal organization and network members to create value (expand the pie) and/or extract value (gain a larger slice of the pie) from the network." We further acknowledge that orchestration is a dynamic activity (Mitrega \& Pfajfar, 2015): It is about "a set of evolving actions, not a static structural position" (Paquin \& Howard-Grenville, 2013, 1624).

This definition implies that two central issues are at play in network orchestration: There are orchestrators (not limited to firms only, but encompassing different actors) who carry out orchestration activities that influence the network and its members. We suggest, first, that different orchestrator types can be identified. We further suggest that while the "set of deliberate actions" generally refers to various activities, such as promoting knowledge mobility or ensuring innovation appropriability (see e.g., Dhanaraj \& Parkhe, 2006), the dynamic nature of orchestration means that not all activities are equally highlighted in all situations, and that they may be carried out in different ways (some more formal, others subtler) (see, Saka-Helmhout \& Ibbott, 2014). Adopting ideas from research that introduces roles as the way to describe what actors do (e.g., Czakon \& Klimas, 2014), we suggest that 
the set of activities that the orchestrator engages in and the managerial approach toward these tasks denotes taking specific orchestrator roles. Finally, we suggest that orchestrator capabilities are relevant in determining whether orchestrators succeed in taking different roles and conducting the activities within them. Figure 1 below is designed to illustrate the central concepts and their relationships. These are discussed in more detail in the following.

[Place Figure 1 about here]

\subsection{Orchestrator types}

Existing research (see e.g., Roijakkers et al., 2013) has gradually made it more perceptible that different orchestrators can be found even in seemingly comparable networks. However, the literature seems to be somewhat divided. There may quite simply be just the notion of an “orchestrator" or a "hub" (e.g., Dhanaraj \& Parkhe, 2006). At the other extreme, quite specific cases have been addressed with a particular organization (e.g., Boeing) and these have been viewed as an orchestrator (e.g., Nambisan \& Sawhney, 2011; Nätti, Hurmelinna-Laukkanen \& Johnston, 2014). The challenge is that without combining these abstract and concrete levels, the discussion easily remains fragmented, thereby hindering theoretical development in the field (Hill, Kern \& White, 2012; Howells, 2006).

We propose a categorization to ease the examination of different orchestrators (see Table 1 below). While in general orchestrators can be central in many ways (e.g., by being widely connected to a variety of actors, centrally located, or uniquely positioned to diffuse information or influence others; Valente et al., 2008), we use as our starting point Busquets' $(2010,482)$ notion that "orchestrators can exert power by controlling resources or exerting a specific role" (see also Goduscheit, 2014). Based on this, we suggest that the resource base of the orchestrator (referring here to monetary resources, intellectual property and other such 
'hard' factors) and the strong relational position in the network (meaning here wide visibility, attractiveness and connectedness; see Gilsing, Cloodt \& Roijakkers, 2016) are of relevance when defining the types of orchestrators. We further believe that the main motivation of the orchestrator is yet another decisive feature: While the viewpoint of Möller \& Svahn (2003) considers network types rather than orchestrator types, they suggest that the ultimate goal and the underlying value system are fundamental. In a similar fashion, the orchestrator can have individual (even opportunistic) or collective (e.g., industry-level, environmental, social) goals (see Roijakkers et al., 2013).

These criteria match with the orchestrator types emerging in the existing literature. Roijakkers et al. (2013) talk about player-orchestrators and non-players. The central difference between the two types, according to Roijakkers et al. (2013) and Leten et al. (2013), is that non-player orchestrators are not active in the end markets and therefore do not constitute a competitive threat to their partners. We consider this categorization very useful, but also suggest that it could be refined.

\subsubsection{Player-orchestrators}

We consider player-orchestrators (following Roijakkers et al., 2013) to be actors whose orchestrator position is based on their resource base and who aim to realize their noticeably individual goals through utilizing the network. The individual goals may be, for example, about surviving and coping in the markets, or benefiting from emerging opportunities (e.g., responding to competitive pressure) (see e.g., Dittrich, Duysters \& de Man, A-P., 2007; Doz, 1996; Gimeno, 2004; Lorenzoni \& Lipparini, 1999; Mariani \& Kylänen, 2014). The eventual goal is the financial wellbeing of the orchestrator (and hopefully, though not necessarily, the benefit of the other network members). IBM, for example, relies on its patent portfolio that both attracts and controls others (see Table 1). Indeed, being part of the network is often a 
prerequisite for the network members to continue business with the player-orchestrator and benefit from the related market access opportunities, for example (Coff, 2010; Gausdal \& Nilsen, 2011). In sum, we define player-orchestrators as for-profit, competitive actors interested in improving their competitive advantages and profitability by leveraging networks that they coordinate.

\subsubsection{Facilitator-orchestrators}

On the other hand, it is possible that intermediating organizations (Howells, 2006) - rather than one resourceful and influential player - are effective in lowering barriers to collaboration and innovation (Batterink et al., 2010). Among "non-players” (see Roijakkers et al., 2013), facilitator-orchestrators act based on their strong relational position and connections rather than securing power with monetary resources or intellectual property (consider e.g., Mobile Monday, which has spread across the world; see Table 1). Neutrality and integrity are important features of these orchestrators. They focus on common interest in the substance matter and viability of the network rather than financial gain for themselves (Fichter, 2009; Hurmelinna-Laukkanen \& Nätti, 2012; Metcalfe, 2010). Networks led by facilitatororchestrators are typically focused on the pre-competitive stage and characterized by independence from any single commercial actor, although they can also function as platforms for more focused innovation activities (see Klerkx \& Aarts, 2013). The benefit for the orchestrators and network members comes in the form of enhancing intellectual capital, professional development and other such aspects. Facilitator-orchestrators can be defined as boundary-spanning actors interested in the development within and of the network as a whole by ensuring the wide spreading of innovative ideas and mutual cooperation.

\subsubsection{Sponsor-orchestrators}


In between the clearest examples of player- and facilitator-orchestrators, a third group can be found. A sponsor-orchestrator may have individual financial goals without being a direct competitor in the end markets. Such orchestrators rely both on resources and strong relational position in networks. They offer resources and connections to the network members, but with the expectation that their effort and investment will be later rewarded. For example, a sponsor-orchestrator may claim membership fees or a commission while promoting the benefits for the network members, or it may acquire joint ownership of the generated innovations (e.g., in case of public research institutes) (Batterink et al., 2010; Leten et al., 2013; Lakhani, 2008). A sponsor-orchestrator's future income may even depend on the success of the innovative firms that it guides. Venture capitalists and business incubators may be central actors in funding innovation, and they therefore may end up conducting orchestration activities in the networks of funded firms (Comacchio, Bonesso \& Pizzi, 2012; Napier et al., 2012). A common feature of the aforementioned is that sponsor-orchestrators may gain future profits depending on the success of others in the network. Therefore, sponsororchestrators can be defined as commercially-oriented actors interested in improving their financial situation by building on the development of the network actors' competitiveness that is promoted by ensuring joint benefit and mutual cooperation. IMEC is an example of an actor that collects fees but aims to promote the wellbeing of the network members (see Table $1)$.

\section{[Place Table 1 about here]}

Naturally, the categorizations may not be completely clear-cut and certain overlap and exceptions can exist ${ }^{2}$. The development of networks is not necessarily linear (Gilsing et al., 
2016). Sometimes the whole network may evolve into something new (Paquin \& HowardGrenville, 2013), which means that the orchestrator may also change in the process.

Nevertheless, at any given point in time the type of orchestrator may be highly relevant. Its characteristics (including attributes such as resources and competence) may enable or restrict certain actions as well as how network members perceive these traits, and how they react and respond to the goals of the orchestrator (see Håkansson \& Ford, 2002). This means that the orchestrator type is likely to be related to the roles that it may undertake.

\subsection{Orchestration roles - bundles of activities conducted in different ways}

The second central issue (in addition to the presence of an orchestrator) emerging in the definition of innovation network orchestration addresses what orchestrators do. Nyström et al. (2014, 484) define roles as "behaviors expected of parties in particular positions."

Orchestration comprises different activities for formulating the network, and directing and managing the practices and processes so as to enable value creation and capture (Batterink et al., 2010). Among the activities, ensuring mobilization (i.e., attracting and engaging relevant actors) and maintaining network stability (making sure that excessive turbulence and member turnover does not occur) are inherently about building and maintaining appropriate structures in an innovation network (see Dhanaraj \& Parkhe, 2006; Van der Borgh, Cloodt \& Romme, 2012). Ensuring knowledge mobility (i.e., making sure that relevant knowledge is available for further assimilation, transformation and exploitation) and innovation appropriability (e.g., ensuring value capture potential and overseeing fair distribution of intellectual property), setting the agenda (opportunity identification and goal drafting), and coordinating (promoting and administrating interaction besides knowledge transfer) relate to ensuring the efficiency and smooth operation of critical undertakings in innovation networks (Dhanaraj \& Parkhe, 2006; Hurmelinna-Laukkanen et al., 2011; Sabatier et al., 2010). 
The (general) orchestration activities outlined above are emphasized to different extents in different situations (see Kirkels \& Duysters, 2010). For example, sometimes knowledge mobility may be highlighted over innovation appropriability or network stability. Likewise, orchestrators may conduct these activities in different ways. Some of these are quite controlled and resemble traditional management (cf. orchestrators functioning as command centers; Czakon \& Klimas, 2014), while others are more facilitation-oriented, subtle and discreet (Hurmelinna-Laukkanen \& Nätti, 2012). For instance, network stability can be upheld by introducing binding contractual arrangements or joint ownership, or by bringing the central actors frequently together for a joint meeting to facilitate common identity building. The different emphases on specific (sets of) activities and the employed level of 'managerial control' translate into orchestrator roles (see e.g., Anderson et al., 1998; Czakon \& Klimas, 2014).

Supporting this idea of orchestrators concentrating on doing different things in different contexts and at different points of the network evolution, the existing literature has labelled a variety of roles that are relevant in taking an innovation network forward. Table 2 below and the following discussion with examples found in previous research provide an overview of the variety of the roles and illustrate the focus on different activities. Simultaneously, they indicate how orchestrator roles and types might be related.

\section{[Place Table 2 about here]}

\subsubsection{Roles in existing literature}

A distinctive orchestrator role is that of an architect (Hinterhuber, 2002). The role-specific activities revolve around mobilization (selecting the network participants, in particular), agenda setting (identification of opportunities, setting the goals) and coordination (especially 
following the resulting plans) (Nambisan \& Sawhney, 2011). In this role, a lot of responsibility and initiative comes from the orchestrator. Similar connotations are present when an orchestrator operates as a judge, adopting a role that emphasizes taking control over plans (Hinterhuber, 2002) and determining, monitoring and adapting performance standards for each participant (Howells, 2006). These roles illustrate a relatively controlling approach toward the mobilization of network members, agenda setting and network-level innovation appropriability.

Likewise, managerial direction from the orchestrator side may be present in roles that highlight knowledge mobility and utilization. A gatekeeper role (Kirkels \& Duysters, 2010; Nyström et al., 2014), for example, refers to extracting knowledge used in the innovation process from outside the network and disseminating it among network members (see also Czakon \& Klimas, 2014; Howells, 2006). Similarly to Wallin (2006), a conductor role comprises activities regarding information acquisition and transmission with the aim of strengthening the focal actor's own core competences, and allocating further tasks to other network members (see also Nambisan \& Sawhney, 2011).

Considering the focus areas and especially the level of direction associated with the above examples, it could be argued that resourceful player-orchestrators rather than facilitators would be the ones to most likely take on the roles of architect, judge, gatekeeper and conductor. This is also because these roles resonate with the importance of the individual goals of orchestrators. The resource base and the associated bargaining power of the players may enable them to set rules and goals that others follow - even though this may be done somewhat reluctantly. For example, Vodafone exerts power as a judge when it requires NDAs to be signed among network members so as to promote innovation appropriability (see Table 2). Also, in these roles the orchestrator will likely succeed if it is willing and able to show a 
readiness to invest in the development work. This is unlikely to happen if no individual benefits are to be achieved and if resources are lacking.

On the other hand, the different orchestration activities can also be carried out in roles that give more room to the network members. Emphasizing the knowledge mobility aspect, a representative role (Kirkels \& Duysters, 2010) encompasses the activities of sharing knowledge about the network to outsiders - and evaluating what can be shared considering innovation appropriability (see also Landsperger et al., 2012). Operating as an external intermediate between network members and as an outside middleman between networks is central in a liaison role (see also Howells, 2006; Goduscheit, 2014). For example, InnoCentive plays this role when acting as a middleman between voluntary innovators and companies in need of help in their innovation process (see Table 2). Furthermore, Kirkels and Duysters (2010) suggest a coordinator role referring to administering the interaction between network members (cf. stability and coordination-related activities). An auctioneer role emphasizes agenda-setting and concentrates on creating a joint vision and promoting that in the network (Wallin, 2006). A developer role (Hinterhuber, 2002) refers to activities of developing and strengthening (in)tangible assets - especially with regard to knowledge mobility.

While acting in these roles requires some resources from the side of the orchestrator as well, the network members can contribute to the network orchestration for their part. Network actors can decide, at least to an extent, if they wish to rely on the orchestrator or manage issues amongst themselves (see Kirkels \& Duysters, 2010). Yet, the input and contribution provided by orchestrators in these roles is valuable for network members, as they provide structure and support beyond mere facilitation. Such benefit for network members gained from reliance on the orchestrator indicates that sponsor-orchestrators would be likely to adopt these roles. 
Finally, among the roles that can be said to be characterized with the least controlling mechanisms for conducting orchestrator activities, the promoter role (Wallin, 2006) reflects getting network members to work toward the same goal (see e.g., Dawson et al., 2014). This may include such goals that may not be obviously attractive in the first phases, but that the orchestrator in the promoter role advances (see Goduscheit, 2014). Another relevant role in this context is the leader role that involves motivating and fostering voluntary collaboration and clarifying the roles of network members. Here, network stability and knowledge mobility become pronounced, and a controlling approach is replaced in these roles with an emphasis on support and discreet influence. For example, OCRI provides an interorganizational space where people can meet and discuss potential synergies and possibilities for common goals for collaboration (see Table 2.).

Considering the resources, strong relational position and motivation of orchestrators, it could be expected that facilitator-orchestrators could be found in the roles described above. They are interested in promoting technological, processual and other, even notably risky (Goduscheit, 2014) advances in a wider context than just for one organization (see Hurmelinna-Laukkanen \& Nätti, 2012). They might not have the resources to do everything themselves, but their neutrality might help in pooling various resources together contrary to player-orchestrators, for example. Players would likely face challenges in promoting genuinely open discussion, especially considering the risk of expropriation and potential competitive tensions (Heiman \& Nickerson, 2004; Leten et al., 2013). As noted by Nyström et al. $(2014,484)$, "the structural approach to roles [...] postulates that actors' positions determine the roles in which they can act."

\subsubsection{Adopting different roles}


The above discussion points toward connectedness between orchestrator types and roles. In particular, it seems that the intrinsic characteristics of the orchestrators drive the focus on specific orchestration activities and the ways in which these are carried out (see e.g., Kirkels \& Duysters, 2010; Roijakkers et al., 2013). In literature, the roles are often described with specific orchestrators in mind, and it is difficult to find the same roles described in relation to different orchestrators (as also depicted in Table 2). This suggests that a link likely exists (see e.g., Ragin, 1987). It seems that the attributes associated with each type allow orchestrators to operate in specific roles (considering e.g., the relevance of resources or strong relational position). On the other hand, this restricts them from adopting a full range of roles because other network members might not accept taking a certain role (considering e.g., competitive tensions within the network).

However, we believe that the orchestrator type alone cannot explain why or how specific roles are adopted, and whether orchestrators can succeed in those roles. We suggest that orchestrator capabilities may be a factor that bridges the orchestrator types and roles. We believe that capabilities maintain or strengthen the original relationship between the type and roles, or change or shift it - depending on the type of the capabilities. These aspects will be discussed below.

\subsection{Different levels of orchestrator capabilities}

In the field of strategic management, Winter (2003) describes how capabilities can reside at different levels by identifying ordinary and higher-order capabilities, as well as 'ad hoc problem solving' as the means to secure survival and success in the organizational context (see also Ritala, Heiman \& Hurmelinna-Laukkanen, 2016). Ordinary, operational capabilities refer, according to this logic, to such capabilities that allow the organization to "make a living," while higher-order capabilities allow creating, modifying and extending these 
capabilities (Winter, 2003, 991). The 'ad hoc' approach refers to activity outside the capability framework; capabilities are, by definition, routinized and cannot be directly applied in the most urgent and unforeseen situations (see Ritala et al., 2016). In a similar vein, Hoopes and Madsen (2008) and Teece (2007), among many others, describe "operational" and "dynamic" capabilities and the underlying differences between them.

The literature on (dynamic) capabilities admittedly involves a lot of debate (see e.g., Kazadi, Lievens \& Mahr, 2016). Möller and Svahn (2003, 211), for example, note that "the main thrust in the discussion on dynamic capabilities has been on how firms integrate, reconfigure, renew and transfer their own or controllable resources", thereby pointing toward a certain internal focus. We nevertheless suggest that the above logic of categorizing capabilities can be usefully adapted to the network orchestration context.

In the following, we draw three important observations from the preceding discussion and use them to explicate how different types of capabilities allow orchestrators to adopt different roles and succeed in conducting the focal activities. Figure 2 below serves as the roadmap in placing the different types of capabilities in our overall conceptual framework. This framing illustrates the intrinsic connections between orchestrator types and roles, and shows the relevant capabilities contributing to orchestrator success.

[Place Figure 2 about here]

\subsubsection{Role-implementation capabilities}

The first observation (that has implications regarding how capabilities connect to orchestrator types and roles) is that adopting an orchestrator role indicates a focus on specific orchestration activities and performing them in specific ways. This calls for, and implies the use of, specific capabilities that we name role-implementation capabilities. Role-implementation capabilities 
can be seen to correspond to the operational capabilities in the established capability discussions (e.g., Hoopes \& Madsen, 2008) ${ }^{3}$. These capabilities allow organizations to perform activities on "an on-going basis using more or less the same techniques on the same scale" (Helfat \& Winter, 2011, 1244). In the network orchestration context, this refers to having such capabilities that allow orchestrators to perform orchestration activities so as to build and manage (in) innovation networks on a daily basis (Kazadi et al., 2016). For this, orchestrators may exploit a variety of capabilities as illustrated in Table 3 below.

[Place Table 3 about here]

However, the connection between orchestrator types and roles indicates that individual orchestrators do not necessarily have (see Vanpoucke, Vereecke \& Wetzels, 2014), or even need, a full range of role-implementation capabilities. While some capabilities may be crucial, others could be next to obsolete in specific roles. For example, being able to ensure knowledge mobility may be essential in a developer role (Hinterhuber, 2002), which means that knowledge processing capabilities are at play. On the other hand, innovation appropriability and the related knowledge protection capabilities could be more pronounced in case of a representative role (Kirkels \& Duysters, 2010).

Different types of orchestrators are likely to have developed specific capabilities (building on and guided by their intrinsic type). In individual roles, they may focus on exploiting and refining those capabilities that are the most relevant for the roles at hand (e.g., Schreyögg \& Kliesch-Eberl, 2007). For example, inherent characteristics may allow playerorchestrators to organize well-specified sub-projects and distributed but coordinated multiparty projects (see García-Canal, Valdés-Llaneza \& Ariño, 2003; Nambisan \& Sawhney, 2011). However, they also need to have suitable role-implementation capabilities to do this. 
This suggests that the relationship between the orchestrator type and roles is maintained (or narrowed down in practice) by the capabilities possessed by the orchestrator.

\subsubsection{Role-switching capabilities}

Orchestrators can rely on their role-implementation capabilities as long as they stay within the specific role they have adopted. However, the second observation drawn from the above discussion is that changes are bound to occur with the development of the networks (Paquin \& Howard-Grenville, 2013). Therefore, we suggest that role-switching capabilities are of relevance. Role-switching capabilities could be argued to be similar to the "sensing and seizing" dimensions of dynamic capabilities, and also to touch upon "reconfiguration" (Teece, 2007). They also resonate with the core ideas of ambidexterity (i.e., "the capacity to simultaneously achieve alignment and adaptability"; Gibson \& Birkinshaw, 2004, 209; see also Zimmermann \& Birkinshaw, 2016).

In the innovation network orchestration context, this refers to the aptitude to detect signs of changes in the network and/or its environment that call for changing the focus of orchestration, and to act accordingly by switching between roles or adopting additional ones. For example, at the beginning of the innovation network life-cycle, activities and roles related to network formation may be prevalent (e.g., Batterink et al., 2010; Mitrega et al., 2012), with orchestrators acting - depending on their type - as judges, leaders or coordinators. Later on, the focus likely turns to (co-)creation, distribution and the exchange of knowledge within innovation networks so as to produce new combinations of knowledge, and to maintain motivation for collaboration (Faems et al., 2007). Then the conductor, gatekeeper, cosmopolitan and developer roles, for example, start to become more pertinent. As commercialization nears, the focus may shift again (Möller \& Rajala, 2007), perhaps leading to roles emphasizing tasks related to network stability, or to the return to roles in which 
network formulation (including relationship termination; Mitrega et al., 2012) can be done efficiently.

It could be argued that this 'life-cycle view' also resonates with how 'networking capabilities" are described in the current literature. The "set of activities and organizational routines which are implemented at the organizational level of the focal company to initiate, develop, and terminate business relationships for the benefit of the company" [emphases added] (Mitrega et al., 2012, 741) could be seen as a manifestation of the role-switching capabilities being used. The ways of defining networking capabilities vary ${ }^{4}$, and they have been developed from other points of view than orchestrator or orchestration as such. In general, however, the overall definition (and the idea that the components of these capabilities could be considered to be role-implementation capabilities: see Table 3 above) indicates that focusing on different aspects at different times is of relevance.

Based on the above discussion, it can be argued that the existence of role-switching capabilities precedes the adoption of new roles (sensing changes is a prerequisite to informed action), and that roles that are adopted as a result of employing role-switching capabilities resonate with the orchestrator type (player, facilitator or sponsor orchestrator). For example, as noted above, while player-orchestrators can be seen to act as judges at some point and architects in other situations, it might be difficult for them to adopt leader roles that expect openness between network members (Heiman \& Nickerson, 2004; Roijakkers et al., 2013). Similar patterns can be seen when examining Table 2 above: Player-orchestrators tend to be found in roles that fit their attributes even if they take on different roles. The organizational embeddedness of capabilities may explain this (see e.g., Schreyögg \& Kliesch-Eberl, 2007; Vergne \& Durand, 2011; Walter et al., 2006).

In sum, it could be argued that the connection between orchestrator types and roles may remain relatively intact when role-switching capabilities are utilized. Relatedly, we suggest 
that role switching is more about changing or shifting the focus between individual activities than about changing the approach and ways of conducting them (e.g., with regard to the level of imposed power and control), or about changing the intrinsic characteristics of an orchestrator. This last notion is also considered in the following part, where yet another category of capabilities is discussed.

\subsubsection{Role-augmentation capabilities}

The third observation brings the notable variety of roles to the center of discussion. The aforementioned suggests that the orchestrator type directs role-taking initially, and that existing capabilities for implementing the most fitting roles and moving between them define how well the orchestrator performs in individual roles and in addressing dynamism. The relationship between the orchestrator type and role also indicates, however, that embracing the variety in roles and stepping into a full range of them would require effort and specific capabilities. These either break the limiting connections or shift the whole relationship into a different context (Kirkels \& Duysters, 2010). In fact, it has been suggested in the industrial networks research tradition that actors can construct their positions, and that adopting new roles is the key to this (Nyström et al., 2014).

Whereas employing role-switching capabilities can be considered to be about reacting to relatively natural changes with the help of the capabilities that already are at the orchestrator's disposal, we suggest that role-augmentation capabilities add yet another layer. We propose that these capabilities resonate with the 'reconfiguring ' side of dynamic capabilities (Teece, 2007) and with ad hoc problem solving (see Ritala et al., 2016). Such capabilities, if available, allow responses to more disruptive (positive or negative) events that network orchestrators may encounter. It may be that the orchestrator needs to change itself, and/or develop or acquire a new set of capabilities, and extend its natural role-base for 
addressing essentially new situations (cf. Barney, 1999; McEvily \& Zaheer, 1999; Winter, 2003).

We suggest that role-augmentation capabilities are the ones that change or shift the relationship between orchestrator types and roles. Different types of orchestrators build on their own characteristics and related strengths when orchestrating innovation networks. This also creates limitations. With role-augmentation capabilities, orchestrators can overcome the initial restrictions. For example, a notable conflict that goes beyond the conflicts that are manageable within the frames of role-implementation capabilities (see e.g., Klerkx \& Aarts, 2013), or the sudden emergence of notable external opportunities, might trigger the need to take atypical roles (see Ritala et al., 2016).

In these situations, role-augmentation capabilities could be realized through repositioning, e.g., deliberately stepping back and letting other actors (such as SMEs with valuable competencies on the outskirts of the network) temporarily guide the network (see Davis \& Eisenhardt, 2011; Ford \& Redwood, 2005). Re-positioning capabilities do not necessarily exist from the start, but they can be developed. They involve sensing the need to take action, but also go much deeper: The orchestrator needs to alter its characteristics, its position or goals (at least temporarily). A risk is present in such a change, which needs to be addressed within the frames of these capabilities. For example, if the neutrality of facilitatororchestrators is lost even for a moment, e.g., if the orchestrator lets some individual firm take a bigger role for some time, it may be very difficult to avoid speculation and prospects that such a thing might happen again (see Fors \& Nyström, 2009; Hurmelinna-Laukkanen \& Nätti, 2012).

Other manifestations of role-augmentation capabilities may also emerge. Ford and Redwood (2005) describe balancing between coercion and conceding to the knowledge and competences of others. This reflects an opportunity to change the approach taken toward 
conducting orchestration activities, and to thereby affect the way in which other network members perceive the orchestrator. This requires profound changes in the orchestrator characteristics and communicating them to the network, or developing and employing persuasion capabilities. A charismatic orchestrator could be capable of stepping in and coordinating the innovation network even if it lacks resources or if its motivation would be questioned under normal circumstances, for example. It is certain that this also involves the ability to sense when relying on persuasion is appropriate (see e.g., Coff, 2010). Misplaced persuasion might change the attitude of the network members toward the orchestrator in negative ways.

The existing literature also includes a third way in which different orchestrators could potentially expand beyond their most inherent roles. This is about relying on the leadershipsharing capabilities and collaborating with other orchestrators. Orchestrators of different networks (e.g., science-based and application-oriented networks) can jointly create a "dual core" (Roijakkers et al., 2013, 15) in order to acquire competences in different substance areas, and capabilities for implementing roles outside their natural sphere. This means that the orchestrator attributes will change, most notably its resources. Table 4 below illustrates these aspects.

[Place Table 4 about here]

What the best approach for each orchestrator type is, and how deep the change in the orchestrator characteristics needs to go, depends on the urgency and necessity of the change, being able to understand these correctly, and then deploying role-augmentation capabilities accordingly. Although the situation at hand may seem to be manageable only through adopting atypical roles, attempting to change the orchestrator type is challenging and risky. There may be "unintended effects of deliberate choices" (Saka-Helmhout \& Ibbott, 2014, 
128). Nevertheless, in some situations role-augmentation also pays off, and the capabilities developed are useful later on as well (Ritala et al., 2016).

\section{CONCLUSIONS}

We started our conceptual study with the goal of understanding how orchestrator type relates to the roles emerging in innovation networks, and how capabilities potentially maintain, shift or change this relationship.

We found that the intrinsic orchestrator type, which does not easily change, is decisive in terms of which roles (i.e., specific sets of orchestration activities conducted with varying degrees of control) the orchestrator can initially take. We concluded that having certain resources, relational positions and goals ensures that the premises for conducting specific activities in certain ways are in place and that network members react positively to orchestration. However, at the same time these characteristics restrict the conducting of activities outside the orchestrators' natural frames.

Examination of the previous literature and practical examples also led us to the conclusion that different types of capabilities maintain or strengthen the orchestrator types and roles, or else they change the initial alignment between them. First, operational roleimplementation capabilities determine the ease and success of executing role-specific activities. These capabilities reside with the orchestrator, and are activated for the purposes of everyday network orchestration (cf. Mitrega et al., 2012). Second, we suggest that roleswitching capabilities allow the orchestrator to move between the roles characteristic of it. These capabilities do not impose radical changes to the relationship between the orchestrator type and roles since they are employed in response to natural dynamism within innovation networks (e.g., Möller \& Rajala, 2007). Finally, role-augmentation capabilities refer to capabilities which are needed when orchestrators aim to adopt roles beyond their natural 
limitations. Role-augmentation capabilities are likely to change the initial relationship of orchestrator type and roles; performing atypical roles may require temporary changes even in the orchestrator attributes.

\subsection{Contributions to theory}

We consider the theoretical contribution of this study to be manifold. First, we combine existing scattered literature and provide conceptual tools and views for future research. With the holistic framework depicted in Figure 2 above, we contribute to the discussion on innovation network orchestration. In particular, we add knowledge on innovation network orchestrator types, orchestration roles $^{5}$ and capabilities, as well as the relationship between them. We further combine the abstract and more specific levels as we examine practical accounts of what orchestration includes, and connect these to theoretical concepts. We also contribute to the discussion on the orchestration tools addressing dynamics in networks (see Mitrega \& Pfajfar, 2015). Regarding the capability perspective, we aimed to produce a proposition on how capability concepts align with the general orchestration discussion (instead of pursuing a detailed account of individual orchestrator capabilities, for example; cf. Kazadi et al., 2016). Subsequently, we contribute to the existing literature by introducing a categorization of orchestrator capabilities held and needed in different orchestration situations. Bringing capabilities into the innovation network context allows the understanding of their nature and applicability.

Combined, these contributions provide one route toward the clarification of concepts in the field of orchestration, and the role of capabilities in that discourse. We also believe that acknowledging the different orchestrator types could be a key in explaining some persistent inconclusive (even contradictory) notions in the network literature, including the debate on 
'managing of' and 'managing in' networks. Different orchestrators could, in fact, approach these in different ways.

\subsection{Managerial implications}

Our managerial contribution lies, first, in the identification of different types of orchestrators and the activities they carry out. Likewise, it is identified how those activities are realized in a variety of orchestrator roles. The introduced framework can be used as an analytical tool for actors managing (and taking part in) networked innovation activities. With the help of this framework, network orchestrators can define their intrinsic orchestrator type, evaluate which roles they can adopt and should pursue, and how to allocate variety of orchestration activities when there are scarce resources.

Second, our framework helps in the managerial challenge of recognizing how to focus on specific activities, i.e., being able to change roles or widen out the orchestration portfolio as the network evolves. We suggest that one central managerial contribution in this research lies in describing the related dynamics. In addition to defining the importance of possessing capabilities related to implementing one's role and switching roles when needed, we aim to define capabilities needed when circumstances call for more profound changes. In dynamic network environments, this might be a highly relevant managerial question: How to implement role-augmentation in the form of repositioning, utilizing persuasion or leadershipsharing capabilities? Generating role-augmentation capabilities can be extremely challenging, for it presumes changing prevailing assumptions and understanding the difficulties involved in changing the orchestration portfolio beyond the orchestrator's natural limitations. Our research can offer a new approach for these adjustments.

\subsection{Limitations and suggestions for future research}


Our study has its limitations. For instance, while we conducted wide keyword-based searches and examined multiple case-based studies and illustrations, other research endeavors might find relevant studies that are missing here. Furthermore, we were unable to include details with regard to different capabilities or orchestration activities, for example, which means that we may have missed some exceptions. Such limitations also provide a basis for future research. For example, defining innovation network orchestration through actions would be worth further examination. Regarding the conceptual issues, research is still needed to determine if the categorization between three types of orchestrators is adequate. We argue that having too many orchestrator types would make examination difficult, but this is not to say that more fine-grained categorization would be pointless. Likewise, the definitions of each type need to be adjusted as different orchestrators are identified and as more attributes become visible. Additionally, while we have chosen not to work toward specific typologies or taxonomies, further research could take these as their goals. Moreover, it goes without saying that empirical examination, both qualitative and quantitative, is needed to verify and establish the ideas brought up in this study. We believe that the approach taken in this study provides both academics and managers with a useful tool for understanding the essence of orchestration. 


\section{REFERENCES}

Anderson, H., Havila, V., Andersen, P. \& Halinen, A. (1998). Position and roleconceptualizing dynamics in business networks. Scandinavian Journal of Management, 14, 167-186.

Barney, J. B. (1999). How a firm's capabilities affect boundary decisions. MIT Sloan Management Review, 40, 137.

Batterink, M.H., Wubben, E.F.M., Klerkx, L. \& Omta, S.W.F. (2010). Orchestrating innovation networks: The case of innovation brokers in the agri-food sector. Entrepreneurship \& Regional Development, 22, 47-76.

Baumeister, R.F. \& Leary, M.R. (1997). Writing narrative literature reviews. Reviews of General Psychology, 1, 311-320.

Belderbos, R., Cassiman, B., Faems, D., Leten, B. \& Van Looy, B. (2014). Co-ownership of intellectual property: Exploring the value-appropriation and value-creation implications of copatenting with different partners. Research Policy, 43, 841-852.

Belussi, F. \& Arcangeli, F. (1998). A typology of networks: flexible and evolutionary firms. Research Policy, 27, 415-428.

Boxenbaum, E. \& Rouleau, L. (2011). New knowledge products as bricolage: Metaphors and scripts in organizational theory. Academy of Management Review, 36, 272-296.

Busquets, J. (2010). Orchestrating Smart Business Network dynamics for innovation. European Journal of Information Systems, 19, 481-493.

Chen, H., Li, Y. \& Liu, Y. (2015). Dual capabilities and organizational learning in new product market performance. Industrial Marketing Management, 46, 204-213.

Coff, R. W. (2010). The coevolution of rent appropriation and capability development. Strategic Management Journal, 31, 711-733.

Comacchio, A., Bonesso, S. \& Pizzi, C. (2012). Boundary spanning between industry and university: The role of Technology Transfer Centres. Journal of Technology Transfer, 37, 943-966.

Convay, S. \& Steward, F. (1998). Mapping innovation networks. International Journal of Innovation Management, 2, 223-254.

Corsaro, D., Cantù, C. \& Tunisi, A. (2012). Actors' heterogeneity in innovation networks Industrial Marketing Management, 41, 780-789.

Czakon, W. and Klimas, P. (2014). Innovative networks in knowledge-intensive industries: How to make them work? An empirical investigation into the Polish Aviation Valley. In: Jemielniak, D. (Ed.). The Laws of the Knowledge Workplace: Changing Roles and the Meaning of Work in Knowledge-intensive Environments. Ashgate Publishing, Ltd., 133-139. 
Davis, J.P. \& Eisenhardt, K.M. (2011). Rotating leadership and collaborative innovation: recombination processes in symbiotic relationships. Administrative Science Quarterly, 56, 159-201.

Dawson, B.K., Young, L., Tu, C. \& Chongyi, F. (2014) Co-innovation in networks of resources - A case study in the Chinese exhibition industry. Industrial Marketing Management, 43, 496-503.

Dhanaraj, C. \& Parkhe, A. (2006). Orchestrating innovation networks, Academy of Management Review, 31, 659-669.

Dittrich, K., Duysters, G. \& de Man, A-P. (2007). Strategic repositioning by means of alliance networks: The case of IBM. Research Policy, 36, 1496-1511.

Dollet, J-N. \& Matalobos, A.D. (2010). Network orchestration in response to customized mass markets of premium wines and spirits. Supply Chain Forum - International Journal, 11, 64-74.

Doz, Y. L. (1996). The evolution of cooperation in strategic alliances: Initial conditions or learning processes? Strategic Management Journal, 17, 55-83.

Driessen, P.H., Kok, R.A.W. \& Hillebrand, B. (2013). Mechanisms for stakeholder integration: Bringing virtual stakeholder dialogue into organizations. Journal of Business Research, 66(9), 1465-1472.

Dyer, J.H. \& Nobeoka, K. (2000). Creating and managing a high-performance knowledge sharing network: The Toyota case. Strategic Management Journal, 21, 239-266.

Dyer, J. H., \& Singh, H. (1998). The relational view: Cooperative strategy and sources of interorganizational competitive advantage. The Academy of Management Review, 23, 660 679.

Faems, D., Janssens, M. \& Van Looy, B. (2007). The initiation and evolution of interfirm knowledge transfer in R\&D relationships. Organization Studies, 28, 1699-1728.

Fichter, K. (2009). Innovation communities: The role of networks of promoters in Open Innovation. R\&D Management, 39, 357-371.

Ford, D. \& Redwood, M. (2005). Making sense of network dynamics through network pictures: A longitudinal case study. Industrial Marketing Management, 34, 648-657.

Fors, J. \& Nyström, A. G. (2009). Network reactions to actor's role change. Proceedings of 25th IMP Conference. 3- 5 September, 2009, Marseille, France.

García-Canal, E., Valdés-Llaneza, A. \& Ariño, A. (2003). Effectiveness of dyadic and multiparty joint ventures. Organization Studies, 24, 743-770.

Gardet, E. \& Mothe, C. (2011). The dynamics of coordination in innovation networks. European Management Review, 8, 213-229. 
Gausdal, A.H. \& Nilsen, E.R. (2011). Orchestrating innovative SME networks. The case of Health Innovation. Journal of the Knowledge Economy, 2, 586-600.

Gibson, C.B. \& Birkinshaw, J. (2004). The antecedents, consequences, and mediating role of organizational ambidexterity. Academy of Management Journal, 47, 209-226.

Gilsing, V., Cloodt, M. \& Roijakkers, N. (2016). From birth through transition to maturation: The evolution of technology-based alliance networks. Journal of Product Innovation Management, 33, 181-200.

Gimeno, J. (2004). Competition within and between networks: The contingent effect of competitive embeddedness on alliance formation. Academy of Management Journal, 47, 820842.

Goduscheit, R.C. (2014). Innovation promoters - A multiple case study. Industrial Marketing Management, 43, 525-534.

Heidenreich, S., Landsperger, J. \& Spieth, P. (2014). Are networks in need of a conductor? Examining the contribution of network managers in low and high complexity settings. Long Range Planning, in press.

Heiman, B.A. \& Nickerson, J.A. (2004). Empirical evidence regarding the tension between knowledge sharing and knowledge expropriation in collaborations. Managerial and Decision Economics, 25, 401-420.

Helfat, C.E., Finkelstein, S., Mitchell, W., Peteraf, M.A., Singh, H., Teece, D.J. \& Winter, S.G., (2007). Dynamic Capabilities: Understanding Strategic Change in Organizations. Blackwell, Oxford, UK.

Helfat, C.E. \& Winter, S.G. (2011). Untangling dynamic and operational capabilities: Strategy for the (N) ever-changing world, Strategic Management Journal, 32, 1243-1250.

Hernandez, E., Sanders, W.M.G. \& Tuschke, A. (2015) Network defense: pruning, grafting, and closing to prevent leakage of strategic knowledge to rivals. Academy of Management Journal, 58, 1233-1260.

Hill, A.D., Kern, D.A. \& White, M.A. (2012). Building understanding in strategy research: The importance of employing consistent terminology and convergent measures. Strategic Organization, 10, 187-200.

Hinterhuber, A. (2002). Value chain orchestration in action and the case of the global agrochemical industry. Long Range Planning, 35, 615-635.

Hoopes D. G. \& Madsen, T. L. (2008): A capability-based view of competitive heterogeneity, Industrial and Corporate Change, 17, 393-426.

Howells, J. (2006). Intermediation and the role of intermediaries in innovation. Research Policy, 35, 715-728. 
Hurmelinna-Laukkanen, P., Möller, K. \& Nätti, S. (2011). Innovation orchestration Matching network types and orchestration profiles. Proceedings of 27th IMP conference, 30 August - 3 September, 2011, Glasgow, Scotland.

Hurmelinna-Laukkanen, P. \& Nätti, S. (2012). Network orchestration for knowledge mobility - The case of an international innovation community. Journal of Business Market Management, 5, 244-264.

Håkansson, H. \& Ford, D. (2002). How should companies interact in business networks? Journal of Business Research, 55, 133-139.

Kazadi, K., Lievens, A. \& Mahr, D. (2016). Stakeholder co-creation during the innovation process: Identifying capabilities for knowledge creation among multiple stakeholders. Journal of Business Research, 692, 525-540.

Kennedy, M.M. (2007). Defining literature. Educational Researcher, 36, 139-147.

Kirkels, Y. \& Duysters, G. (2010). Brokerage in SME networks. Research Policy, 39, 375385 .

Klerkx, L. \& Aarts, N. (2013). The interaction of multiple champions in orchestrating innovation networks: Conflicts and complementarities. Technovation, 33, 193-210.

Lakhani, K.R. (2008) InnoCentive.com. Harvard Business School Case, N9-608-170.

Landsperger, J., Spieth, P. \& Heidenreich, S. (2012). How network managers contribute to innovation network performance. International Journal of Innovation Management, 16, 1-21.

Laperche, B., Munier, F. \& Hamdouch, A. (2008). The collective innovation process and the need for dynamic coordination: general presentation. Journal of Innovation Economics \& Management, 2, 3-13.

Lee, S. C., Chang, S. N., Liu, C. Y. \& Yang, J. (2007). The effect of knowledge protection, knowledge ambiguity, and relational capital on alliance performance. Knowledge and Process Management, 14, 58.

Leischnig, A., Geigenmueller, A. \& Lohmann, S. (2014). On the role of alliance management capability, organizational compatibility, and interaction quality in interorganizational technology transfer. Journal of Business Research, 676, 1049-1057.

Leten, B., Vanhaverbeke, W., Roijakkers, N., Clerix, A. \& Van Helleputte, J. (2013). IP models to orchestrate innovation ecosystems: IMEC, a public research institute in nanoelectronics. California Management Review, 55, 51-64.

Lorenzoni, G. \& Lipparini, A. (1999). The leveraging of interfirm relationships as a distinctive organizational capability: a longitudinal study. Strategic Management Journal, 20, 317-338. 
Mariani, M. M. \& Kylänen, M. (2014). The relevance of public-private partnerships in coopetition: Empirical evidence from the tourism sector. International Journal of Business Environment, 6, 106-125.

McDermott, G., Mudambi, R. \& Parente, R. (2013). Strategic modularity and the architecture of multinational firm. Global Strategy Journal, 3, 1-7.

McEvily, B. \& Zaheer, A. (1999). Bridging ties: A source of firm heterogeneity in competitive capabilities. Strategic Management Journal, 20, 1133-1156.

Metcalfe, A.S. (2010). Examining the trilateral networks of the triple helix: Intermediating organizations and academy-industry-government relations. Critical Sociology, 36, 503-519.

Mitrega, M., Forkmann, S., Ramos, C. \& Henneberg, S. C. (2012). Networking capability in business relationships - Concept and scale development. Industrial Marketing Management, $41,739-751$.

Mitrega, M. \& Pfajfar, G. (2015). Business relationship process management as company dynamic capability improving relationship portfolio. Industrial Marketing Management, 46, 193-203.

Möller, K. \& Rajala, A. (2007). Rise of strategic nets - New modes of value creation. Industrial Marketing Management, 36, 895-908.

Möller, K. \& Svahn, S. (2003). Managing strategic nets a capability perspective. Marketing Theory, 3, 209-234.

Nambisan, S. \& Sawhney, M. (2011). Orchestration Processes in Network-Centric Innovation: Evidence from the Field. Academy of Management Perspectives, 25, 40-57.

Napier, G., Rouvinen, P., Johansson, D., Finnbjörnsson, T., Solberg, E. \& Pedersen, K. (2012). The Nordic Growth Entrepreneurship Review 2012 NGER. Nordic Innovation Publication 2012: 25 Final report.

Nyström, A.G., Leminen, S., Westerlund, M. \& Kortelainen, M. (2014). Actor roles and role patterns influencing innovation in living labs. Industrial Marketing Management, 43, 483495.

Nätti, S., Hurmelinna-Laukkanen, P. \& Johnston, W. (2014). Absorptive capacity and network orchestration in innovation communities - Promoting service innovation. Journal of Business and Industrial Marketing, 29, 173 - 184.

Paquin, R.L. \& Howard-Grenville, J. (2013). Blind dates and arranged marriages: Longitudinal processes of network orchestration. Organization Studies, 34, 1623-1653.

Pentland, D., Forsyth, K., Maciver, D., Walsh, M., Murray, R., Irvine, L. \& Sikora, S. (2011). Key characteristics of knowledge transfer and exchange in healthcare: integrative literature review. Journal of Advanced Nursing, 67, 1408-1425. 
Pittaway, L., Robertson, M., Munir, K., Denyer, D. \& Neely A. (2004). Networking and innovation: A systematic review of the evidence. International Journal of Management Reviews, 5/6, 137-68.

Ragin, C. C. (1987). The comparative method. Moving beyond qualitative and quantitative strategies. University of California Press. Oakland, California, USA.

Reinartz, W., Krafft, M. \& Hoyer, W. D. (2004). The customer relationship management process: Its measurement and impact on performance. Journal of marketing research, 413, 293-305.

Reypens, C., Lievens, A. \& Blazevic, V. (2016). Leveraging value in multi-stakeholder innovation networks: A process framework for value co-creation and capture. Industrial Marketing Management.

Ritala, P., Heiman, B. \& Hurmelinna-Laukkanen, P. (2016). The need for speed - Unfamiliar problems, capability rigidity, and ad hoc processes in organizations. Industrial and Corporate Change, 25, 757-777.

Ritter, T. \& Geersbro, J. (2011). Organizational relationship termination competence: A conceptualization and an empirical test. Industrial Marketing Management, 406, 988-993.

Roijakkers, N., Leten, B., Vanhaverbeke, W., Clerix, A. \& Van Helleputte, J. (2013). Orchestrating Innovation Ecosystems_IMEC. Proceedings of the 35th DRUID Conference 2013, Barcelona, Spain, June 17-19.

Sabatier, V., Mangematin, V. \& Rousselle, T. (2010). Orchestrating networks in the biopharmaceutical industry: small hub firms can do it. Production Planning and Control, 21, 218-228.

Saka-Helmhout, A. \& Ibbott, C. J. (2014). Network Orchestration: Vodafone's journey to globalization. Advances in International Management, 27, 123-149.

Schreyögg, G. \& Kliesch-Eberl, M. (2007). How dynamic can organizational capabilities be? Towards a dual-process model of capability dynamization, Strategic Management Journal, 28, 913-933.

Shepherd, D. A. \& Suddaby, R. (2017). Theory Building: A Review and Integration, Journal of Management, 43, 59-86.

Shih, W., Pisano, G. \& King, A. A. (2008). Radical collaboration: IBM microelectronics joint development alliances. Harvard Business School Case: 608-121.

Sullivan M. G. \& Weerawardena, J. (2006). Networking capability and international entrepreneurship: How networks function in Australian born global firms. International Marketing Review, 23, 549-572.

Teece, D. J. (2007). Explicating dynamic capabilities: the nature and microfoundations of (sustainable) enterprise performance. Strategic Management Journal, 28, 1319-1350. 
Valente, T. W., Coronges, K., Lakon, C. \& Costenbader, E. (2008). How correlated are network centrality measures? Connections (Toronto, Ont.), 28, 16.

Van der Borgh, M., Cloodt, M. \& Romme, A. G. L. (2012). Value creation by knowledgebased ecosystems: Evidence from a field study. $R \& D$ Management, 42, 150-169.

Vanpoucke, E., Vereecke, A. \& Wetzels, M. (2014). Developing supplier integration capabilities for sustainable competitive advantage: a dynamic capabilities approach. Journal of operations management, 327, 446-461.

Vergne, J. P. \& Durand, R. (2011), The path of most persistence: An evolutionary perspective on path dependence and dynamic capabilities, Organization Studies, 32, 365-382.

Verhoeven, K. B. T. \& Maritz, A. (2012). Collaboration for innovation: Network processes and capabilities. ISPIM Conference Proceedings: Manchester: The International Society for Professional Innovation Management ISPIM, 1-18.

Wallin, J. (2006). Business Orchestration: Strategic Leadership in the Era of Digital Convergence. Wiley \& Sons, Chichester, England.

Walter, A., Auer, M. \& Ritter, T. (2006). The impact of network capabilities and entrepreneurial orientation on university spin-off performance. Journal of business venturing, 214, 541-567.

Winter, S. G. (2003). Understanding dynamic capabilities. Strategic Management Journal, 24, 991-995.

Zimmermann, A. \& Birkinshaw, J. (2016). Reconciling Capabilities and Ambidexterity Theories: A Multi-Level Perspective. In: Teece, D.J. and Leih, S. (Eds.) The Oxford Handbook of Dynamic Capabilities. Oxford University Press, 1-24. 
Figure 1. Central concepts in the study

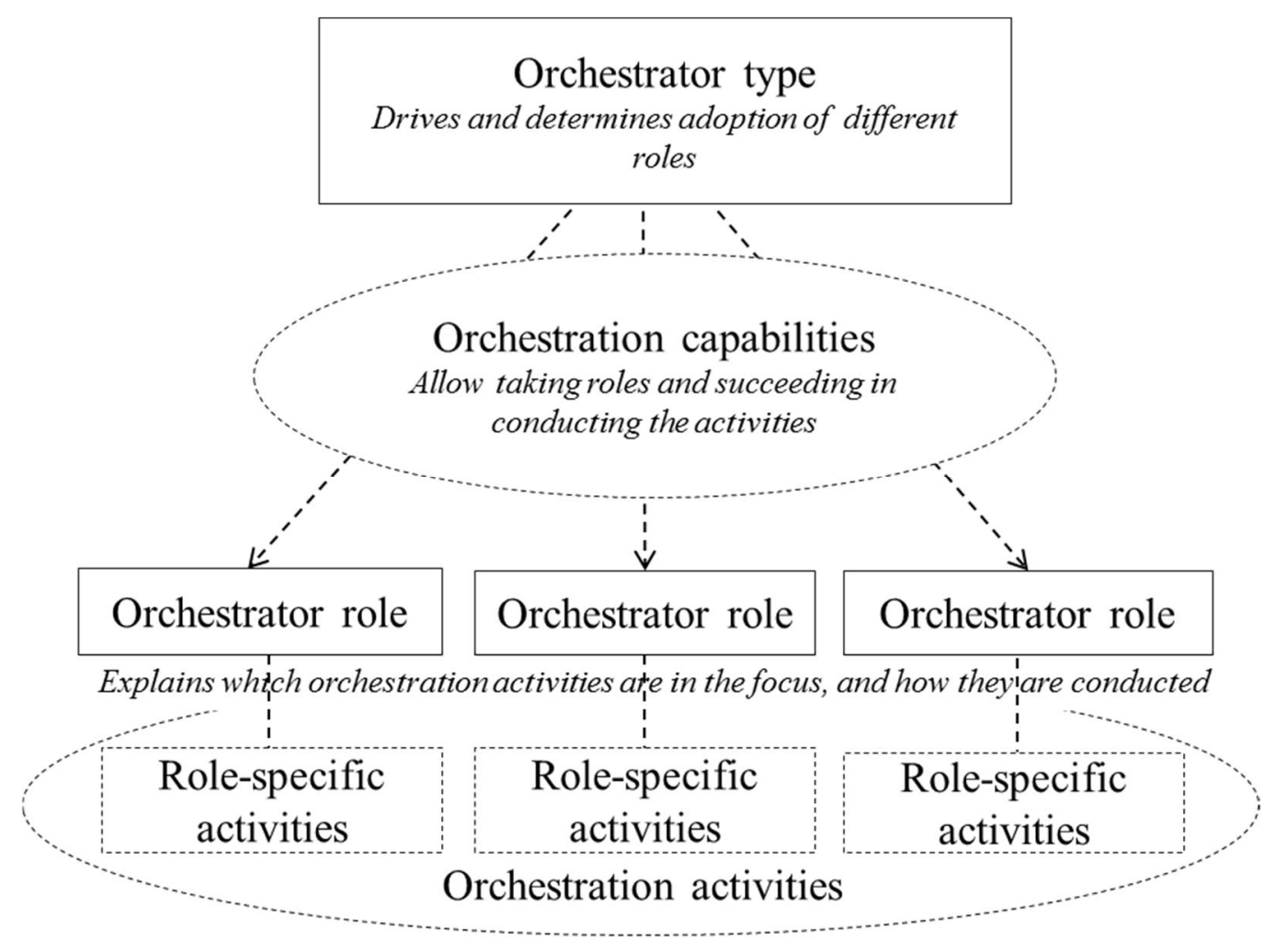


Figure 2. Conceptual framework - Illustration of orchestrator types, roles and capabilities (NW=network)

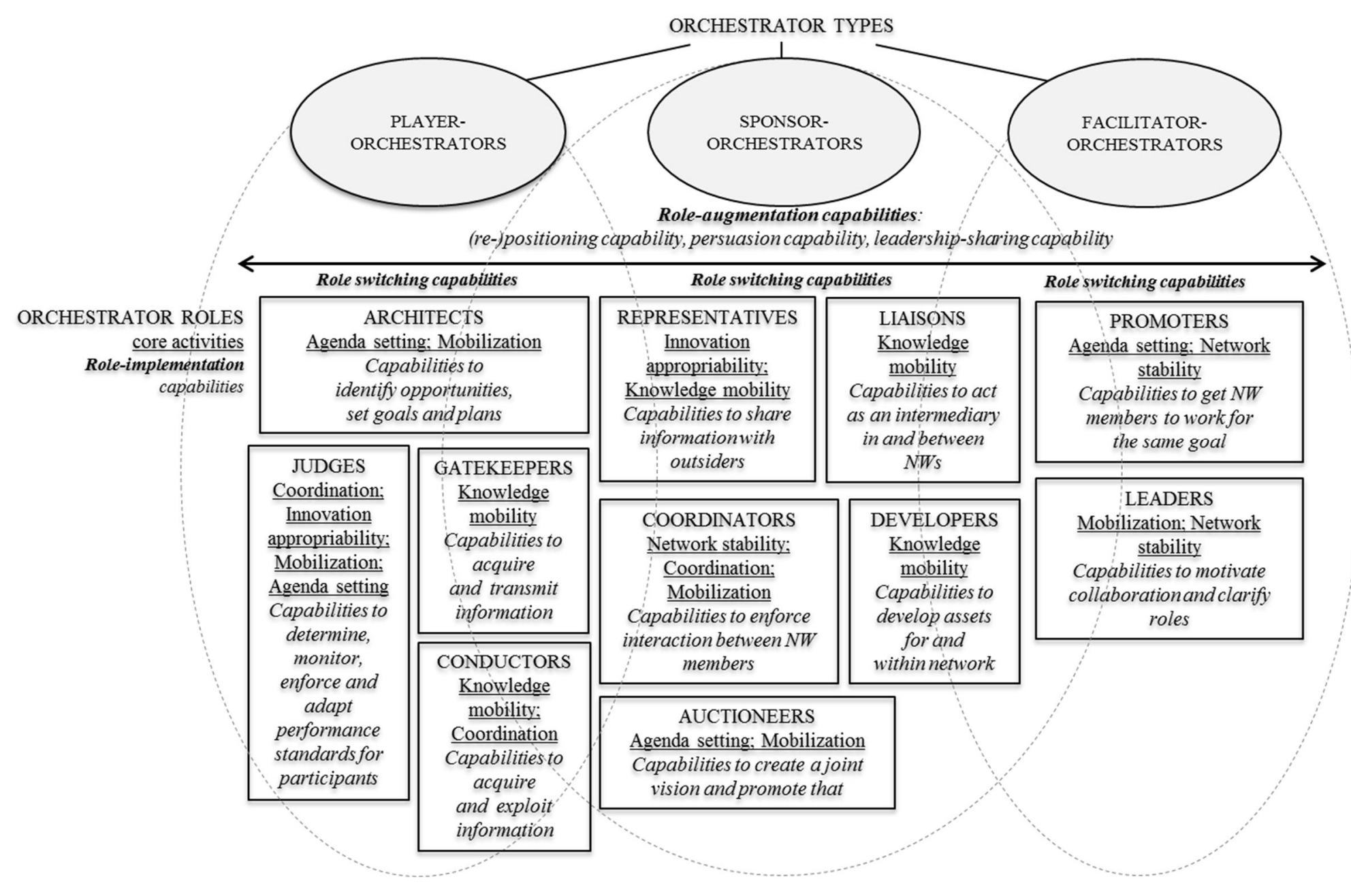




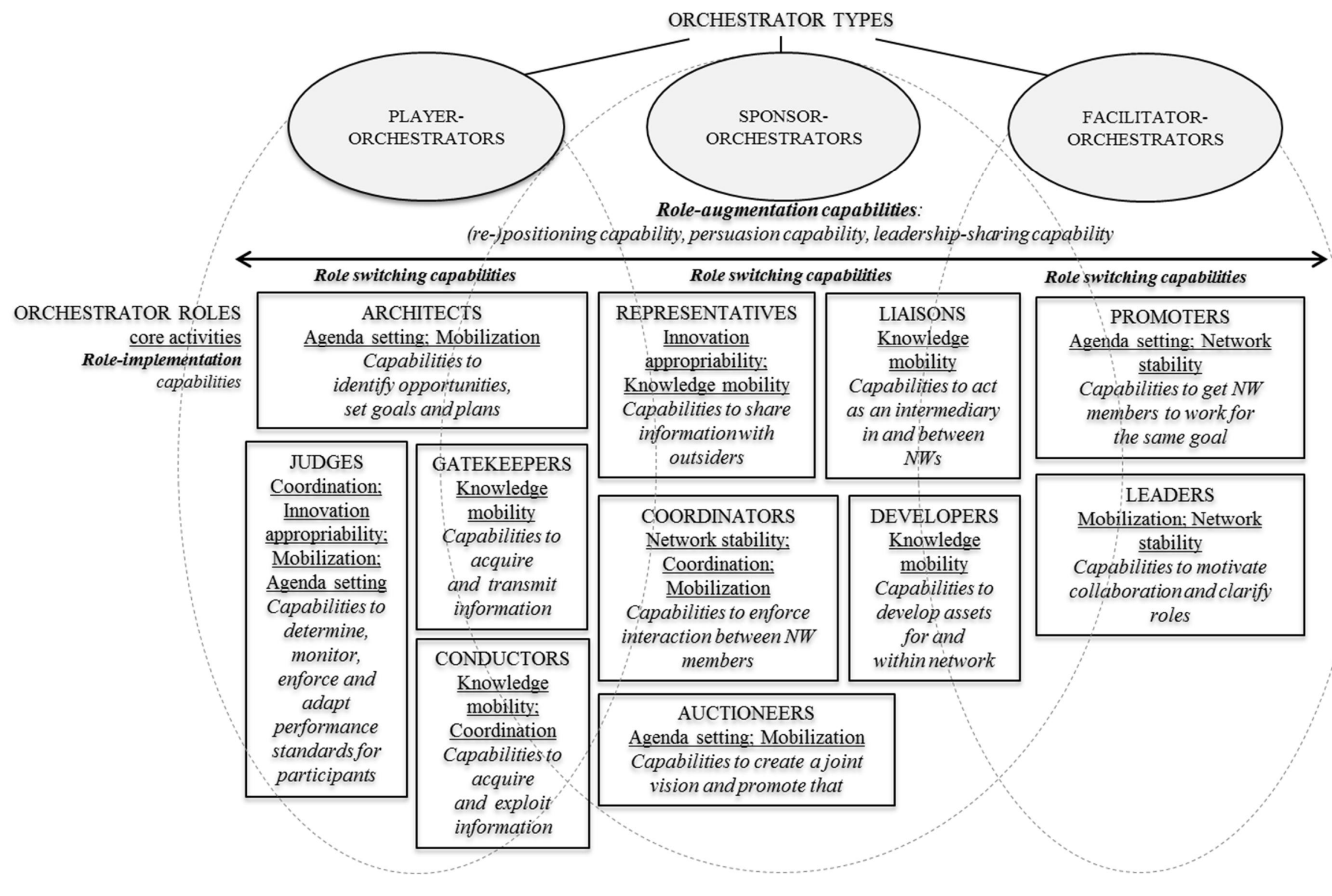


Table 1. Orchestrator types.

\begin{tabular}{|c|c|c|c|}
\hline $\begin{array}{l}\text { Orchestrator } \\
\text { type }\end{array}$ & Definition & Characteristics & Illustrations from existing research \\
\hline $\begin{array}{l}\text { Player- } \\
\text { orchestrators }\end{array}$ & $\begin{array}{l}\text { For-profit, } \\
\text { competitive actors } \\
\text { interested in } \\
\text { improving their } \\
\text { competitive } \\
\text { advantages and } \\
\text { profitability by } \\
\text { leveraging networks } \\
\text { that they coordinate }\end{array}$ & $\begin{array}{l}\text {-strong resource base } \\
\text { - competitive } \\
\text { orientation } \\
\text { - individual goals } \\
\text { highlighted } \\
\text { - (relatively) short- } \\
\text { term perspective for } \\
\text { profiting }\end{array}$ & $\begin{array}{l}\text { - IBM "tries to keep up with the largest } \\
\text { players by joining forces with other } \\
\text { (smaller) players to share R\&D costs } \\
\text { and risks" (Roijakkers et al., 2013, 14; } \\
\text { see also Dittrich et al., 2007; Shih, } \\
\text { Pisano \& King, 2008). [Individual } \\
\text { goals] } \\
\text { IBM utilizes its strong patent portfolio } \\
\text { (resources) to "convince firms to join } \\
\text { the innovation ecosystem" (Roijakkers } \\
\text { et al., 2013, 13). [Reliance on strong } \\
\text { resource base] } \\
\text { - Boeing: "Although each global } \\
\text { partner had considerable autonomy } \\
\text { with regard to the design of the } \\
\text { individual components, Boeing } \\
\text { remained the central decision maker in } \\
\text { the network" (Nambisan and Sawhney, } \\
\text { 2011, 41). [Individual goals, } \\
\text { competitive orientation] } \\
\text { - DuPont: "In the creation of the new } \\
\text { business system [to follow its own } \\
\text { strategic development plans] DuPont } \\
\text { relies heavily on strategic alliances" } \\
\text { (Hinterhuber, 2002, 627). [ Individual } \\
\text { goals] } \\
\text { - Vodafone chose "a particular strategy } \\
\text { in response to a specific objective." } \\
\text { "Vodafone objective [was] to attain } \\
\text { cash synergies" (Saka-Helmhout and } \\
\text { Ibbott, 2014, 128; 133). [individual } \\
\text { goals] }\end{array}$ \\
\hline $\begin{array}{l}\text { Facilitator- } \\
\text { orchestrators }\end{array}$ & $\begin{array}{l}\text { Boundary spanning } \\
\text { actors interested in } \\
\text { the development } \\
\text { within and of the } \\
\text { network as a whole } \\
\text { by ensuring wide } \\
\text { spread of innovative } \\
\text { ideas and mutual } \\
\text { cooperation }\end{array}$ & $\begin{array}{l}\text { - collective goals } \\
\text { - strong relational } \\
\text { position based on } \\
\text { neutrality and } \\
\text { integrity (unofficial } \\
\text { brokering) } \\
\text { - non-competitive } \\
\text { orientation }\end{array}$ & $\begin{array}{l}\text { - Mobile Monday network (MoMo) is a } \\
\text { network of voluntary people active in } \\
\text { developing the mobile application } \\
\text { industry (www.mobilemonday.net) and } \\
\text { has been characterized as a "free } \\
\text { forum of discussion and networking } \\
\text { [with the goal] to facilitate } \\
\text { innovativeness of mobile application } \\
\text { industry" [collective goals] } \\
\text { (Hurmelinna-Laukkanen \& Nätti, } \\
\text { 2012, 250; see also Nätti, Hurmelinna- } \\
\text { Laukkanen \& Johnston, 2014 ). The } \\
\text { coordinators of the network do not } \\
\text { benefit commercially from the } \\
\text { community (Hurmelinna-Laukkanen \& } \\
\text { Nätti, 2012). [non-competitive } \\
\text { orientation; neutrality] }\end{array}$ \\
\hline
\end{tabular}




\begin{tabular}{|c|c|c|c|}
\hline & & & $\begin{array}{l}\text { - Ottawa Centre for Research and } \\
\text { Innovation (OCRI) "is a nonprofit, } \\
\text { membership-based organization" and } \\
\text { "serves an intermediating function by } \\
\text { brokering an interorganizational space" } \\
\text { (Metcalfe, 2010, 510). [non- } \\
\text { competitive orientation; strong } \\
\text { relational position] }\end{array}$ \\
\hline $\begin{array}{l}\text { Sponsor- } \\
\text { orchestrators }\end{array}$ & $\begin{array}{l}\text { Commercially } \\
\text { oriented actors } \\
\text { (venture capitalists, } \\
\text { technology centers) } \\
\text { interested in } \\
\text { improving their } \\
\text { financial situation by } \\
\text { building on the } \\
\text { development of the } \\
\text { network actors' } \\
\text { competitiveness that } \\
\text { is promoted by } \\
\text { ensuring joint benefit } \\
\text { and mutual } \\
\text { cooperation }\end{array}$ & $\begin{array}{l}\text { - mix of individual } \\
\text { and collective goals } \\
\text { - specific nodal } \\
\text { position based on } \\
\text { relational and } \\
\text { financial resources } \\
\text { (official brokering) } \\
\text { - (relatively) long- } \\
\text { term perspective for } \\
\text { profiting }\end{array}$ & $\begin{array}{l}\text { - Veraventure is a "venture capital } \\
\text { investment company serving as the hub } \\
\text { for public early-stage venture capital } \\
\text { investments" (www.finnvera.fi/eng). } \\
\text { [specific nodal position] } \\
\text { - IMEC: The goal of IMEC is to } \\
\text { generate knowledge around new } \\
\text { technologies jointly with its partners, } \\
\text { not to become the leader in the field. } \\
\text { IMEC gains benefits from being an } \\
\text { orchestrator in the form of program } \\
\text { fees and co-ownership of the output } \\
\text { (Leten et al., 2013). [mix of individual } \\
\text { and collective goals] } \\
\text { - InnoCentive gains income based on } \\
\text { fixed fees from solution seekers, and } \\
\underline{\text { combines various actors in the search }} \\
\text { for best solutions to different R\&D } \\
\text { problems (Lakhani, 2008). [mix of } \\
\text { individual and collective goals, specific } \\
\text { nodal position] }\end{array}$ \\
\hline
\end{tabular}


Table 2. Orchestrator roles - central activities and level of managerial control.

\begin{tabular}{|c|c|c|c|c|c|c|c|c|}
\hline \multirow[t]{5}{*}{$\begin{array}{l}\text { Way of } \\
\text { conducting } \\
\text { activities/ } \\
\text { level of } \\
\text { managerial } \\
\text { control }\end{array}$} & Roles & $\begin{array}{l}\text { Promoting } \\
\text { mobilization }\end{array}$ & $\begin{array}{l}\text { Promoting network } \\
\text { stability }\end{array}$ & $\begin{array}{l}\text { Ensuring knowledge } \\
\text { mobility }\end{array}$ & $\begin{array}{l}\text { Ensuring innovation } \\
\text { appropriability }\end{array}$ & Setting agenda & Coordinating & \multirow{5}{*}{$\begin{array}{l}\text { Plausible } \\
\text { orchestrator } \\
\text { type taking } \\
\text { the role }\end{array}$} \\
\hline & Architect & $\begin{array}{l}\text { Selecting the network } \\
\text { participants } \\
\text { E.g., Dupont expels } \\
\text { under-performing } \\
\text { companies (Hinterhuber, } \\
\text { 2002) }\end{array}$ & & & & $\begin{array}{l}\text { Identifying opportunities, } \\
\text { setting the goals } \\
\text { E.g., IBM "collaborates } \\
\text { with various fablite firms } \\
\text { and IDMs to develop } \\
\text { semiconductor process } \\
\text { technology" (Roijakkers } \\
\text { et al., 2013) }\end{array}$ & $\begin{array}{l}\text { Following the plans } \\
\text { E.g., Boeing: } \\
\text { "Integration tools } \\
\text { employed were geared } \\
\text { towards two primary } \\
\text { objectives: Gaining } \\
\text { increased visibility of } \\
\text { actions [...] and } \\
\text { motivating partners to } \\
\text { take actions that would } \\
\text { improve such visibility" } \\
\text { (Kotha and Srikanth } \\
\text { 2013) }\end{array}$ & \\
\hline & Judge & $\begin{array}{l}\text { Defining and initiating } \\
\text { the network } \\
\text { E.g., IBM increased the } \\
\text { number of new partners } \\
\text { and searched for } \\
\text { partners outside its core } \\
\text { business (Dittrich et al., } \\
\text { 2007) }\end{array}$ & & & $\begin{array}{l}\text { Setting the IP rules for } \\
\text { value appropriation } \\
\text { E.g., Vodafone: "It was a } \\
\text { requirement that each } \\
\text { attending company sign } \\
\text { a group NDA" (Saka- } \\
\text { Helmhout and Ibbott, } \\
\text { 2014) }\end{array}$ & $\begin{array}{l}\text { Taking control over } \\
\text { plans, determining } \\
\text { performance standards } \\
\text { E.g., Boeing: "As a } \\
\text { platform leader, a hub } \\
\text { firm defines and offers a } \\
\text { basic innovation } \\
\text { architecture" (Nambisan } \\
\text { and Sawhney 2011) }\end{array}$ & $\begin{array}{l}\text { Monitoring and adapting } \\
\text { performance standards } \\
\text { E.g., DuPont manages } \\
\text { performance standards } \\
\text { "through predefined } \\
\text { service level } \\
\text { agreements" } \\
\text { (Hinterhuber, 2002) }\end{array}$ & \\
\hline & Gatekeeper & & & $\begin{array}{l}\text { Extracting knowledge } \\
\text { from outside the network } \\
\text { and disseminating it } \\
\text { among network members } \\
\text { E.g., Apple drew } \\
\text { "together collaborative } \\
\text { external resources from } \\
\text { the likes of Texas } \\
\text { Instruments, Toshiba and } \\
\text { Sharp" (Jones 2008) } \\
\text { She }\end{array}$ & & & & \\
\hline & Conductor & & & $\begin{array}{l}\text { Acquiring and } \\
\text { transforming information } \\
\text { to strengthen the focal } \\
\text { actor's own core } \\
\text { competences } \\
\text { E.g., Vodafone: "There } \\
\text { was a polarizing } \\
\text { Vodafone objective to }\end{array}$ & & & $\begin{array}{l}\text { Allocating tasks to other } \\
\text { network members } \\
\text { E.g., Boeing focused on } \\
\text { offering its partners a } \\
\text { common set of design to } \\
\text { enhance module } \\
\text { interoperability }\end{array}$ & \\
\hline
\end{tabular}




\begin{tabular}{|c|c|c|c|c|c|}
\hline & & $\begin{array}{l}\text { attain cash synergies in } \\
\text { the network } \\
\text { infrastructure supply } \\
\text { chain and with an } \\
\text { acceptance that the } \\
\text { benefits arising thereof } \\
\text { may be asymmetric and } \\
\text { not shared" (Saka- } \\
\text { Helmhout and Ibbott } \\
\text { 2014) }\end{array}$ & & $\begin{array}{l}\text { (Nambisan and Sawhney, } \\
\text { 2011) }\end{array}$ & \\
\hline Representative & & $\begin{array}{l}\text { Sharing knowledge on } \\
\text { the network with } \\
\text { outsiders; } \\
\text { Providing and filtering } \\
\text { information } \\
\text { E.g., Peacritt "provides } \\
\text { situation analysis by a } \\
\text { technical expert [...] to } \\
\text { identify specific } \\
\text { problems and related } \\
\text { knowledge needs [...] } \\
\text { [based on that analysis] } \\
\text { It costs little of nothing } \\
\text { for entrepreneurs to get } \\
\text { involved in potential } \\
\text { projects" (Batterink et } \\
\text { al., 2010) }\end{array}$ & $\begin{array}{l}\text { Evaluating how much } \\
\text { can be shared to maintain } \\
\text { innovation } \\
\text { appropriability } \\
\text { E.g., IMEC: "IAP } \\
\text { [Industrial affiliation } \\
\text { programs] partners } \\
\text { obtain access to valuable } \\
\text { IMEC background IP at } \\
\text { an early stage [...] } \\
\text { IMEC only selectively } \\
\text { provides licences to } \\
\text { important background } \\
\text { technologies" (Leten et } \\
\text { al., 2013) }\end{array}$ & & \\
\hline Liaison & & $\begin{array}{l}\text { Operating as an external } \\
\text { intermediate between } \\
\text { network members or } \\
\text { networks; } \\
\text { E.g., "IMEC's neutrality } \\
\text { helps in playing on } \\
\text { orchestrator role as it } \\
\text { creates an environment } \\
\text { where partners are } \\
\text { willing to openly discuss } \\
R \& D \text { roadmaps" } \\
\text { (Roijakkers et al., 2013) }\end{array}$ & & $\begin{array}{l}\text { Shaping and advancing } \\
\text { exchange processes: } \\
\text { E.g., InnoCentive is } \\
\text { "eBay of innovation" } \\
\text { (Lakhani, 2008) }\end{array}$ & $\begin{array}{l}\text { Sponsor- } \\
\text { orchestrators }\end{array}$ \\
\hline Coordinator & $\begin{array}{l}\text { Administrating } \\
\text { interaction between } \\
\text { network members for } \\
\text { increasing ties: } \\
\text { E.g., Veraventure: } \\
\text { "Finnvera's own experts } \\
\text { help in searching for } \\
\text { external help; } \\
\text { Specialized, experienced }\end{array}$ & & & $\begin{array}{l}\text { Practical administration } \\
\text { of interaction between } \\
\text { network members, } \\
\text { E.g., IMEC: "IAP [...] is } \\
\text { a partnership formula for } \\
\text { joint } R \& D \text { by industrial } \\
\text { researchers and IMEC } \\
\text { research teams focused } \\
\text { on a specific technology" } \\
\text { (Roijakkers et al., 2013) }\end{array}$ & \\
\hline
\end{tabular}




\begin{tabular}{|c|c|c|c|c|c|c|c|c|}
\hline & & & $\begin{array}{l}\text { consultants" } \\
\text { (www.Finnvera.fi) }\end{array}$ & & & & & \\
\hline & Auctioneer & $\begin{array}{l}\text { Creating a joint vision } \\
\text { and promoting it } \\
\text { E.g., "InnoCentive's } \\
\text { approach was intended } \\
\text { [...] to connect seekers } \\
\text { with solvers" (Lakhani, } \\
\text { 2008) }\end{array}$ & & & & $\begin{array}{l}\text { Introducing a joint } \\
\text { vision: } \\
\text { E.g., "InnoCentive's } \\
\text { approach was intended } \\
\text { [...] to increase the } \\
\text { "productivity" of } \\
\text { problem solving" } \\
\text { (Lakhani, 2008) }\end{array}$ & & \\
\hline & Developer & & & $\begin{array}{l}\text { Developing and } \\
\text { strengthening the } \\
\text { (in)tangible assets } \\
\text { E.g., IMEC is active in } \\
\text { offering relevant } \\
\text { ecosystem-specific } \\
\text { technological expertise } \\
\text { to its partners (Leten et } \\
\text { al., 2013; Roijakkers et } \\
\text { al., 2013) }\end{array}$ & $\begin{array}{l}\text { Strengthening the } \\
\text { intangible assets } \\
\text { E.g., IMEC: "Majority of } \\
\text { the foreground } \\
\text { knowledge is shared } \\
\text { among partners through } \\
\text { non-exclusive licensing } \\
\text { agreements" (Leten et } \\
\text { al., 2013) }\end{array}$ & & & \\
\hline & Promoter & & $\begin{array}{l}\text { Engaging actors into an } \\
\text { innovation development } \\
\text { process } \\
\text { E.g., Mobile Monday: } \\
\text { "Free forum for } \\
\text { discussion and } \\
\text { networking" } \\
\text { (Hurmelinna-Laukkanen } \\
\text { and Nätti 2012) }\end{array}$ & & & $\begin{array}{l}\text { Introducing new ideas } \\
\text { into the network; Getting } \\
\text { network members to } \\
\text { work toward the same } \\
\text { goal } \\
\text { E.g., Mobile Monday: } \\
\text { "Main goal is to } \\
\text { facilitate innovativeness } \\
\text { of mobile application } \\
\text { industry" (Hurmelinna- } \\
\text { Laukkanen and Nätti, } \\
\text { 2012) }\end{array}$ & & Facilitator- \\
\hline $\begin{array}{l}\text { Approach of } \\
\text { discrete } \\
\text { influence } \\
\text { and enabling }\end{array}$ & Leader & $\begin{array}{l}\text { Motivating and fostering } \\
\text { (spontaneous) } \\
\text { collaboration } \\
\text { E.g., Ottawa Centre for } \\
\text { Research and } \\
\text { Innovations (OCRI): } \\
\text { "Participation on the } \\
\text { OCRI board is a shared } \\
\text { experience that allows } \\
\text { each actor to make } \\
\text { contacts across the } \\
\text { public-private divide" } \\
\text { (Metcalfe, 2010) }\end{array}$ & $\begin{array}{l}\text { Providing support; } \\
\text { managing the texture of } \\
\text { interactions with long- } \\
\text { term view } \\
\text { E.g., Mobile Monday: } \\
\text { "The coordinators of } \\
\text { Mobile Monday try to } \\
\text { ensure neutrality, } \\
\text { integrity and social } \\
\text { integration in the } \\
\text { network" (Nätti et al., } \\
\text { 2014) }\end{array}$ & & & $\begin{array}{l}\text { Specifying contributions } \\
\text { to the orchestrator, to the } \\
\text { network, to others; } \\
\text { specifying benefits of } \\
\text { participation } \\
\text { E.g., Ottawa Centre for } \\
\text { Research (OCRI) and " } \\
\text { Innovations provides "an } \\
\text { interorganizational } \\
\text { space where individuals } \\
\text { from public and private } \\
\text { entities can meet, discuss } \\
\text { mutually supportive } \\
\text { goals and strategize } \\
\text { ways to achieve those } \\
\text { goals" }\end{array}$ & $\begin{array}{l}\text { Clarifying the roles of } \\
\text { network members } \\
\text { E.g., Ottawa Centre for } \\
\text { Research and } \\
\text { Innovations (OCRI): } \\
\text { "OCRI hosts an annual } \\
\text { technology showcase --- } \\
\text { the showcase has the } \\
\text { ability to shape the } \\
\text { market in that it becomes } \\
\text { a 'who's who' of start- } \\
\text { ups and companies" } \\
\text { (Metcalfe, 2010) }\end{array}$ & orchestrators \\
\hline
\end{tabular}


Table 3. Role-implementation capabilities by orchestration activities.

\begin{tabular}{|c|c|c|c|c|c|c|}
\hline $\begin{array}{l}\text { Orchestration } \\
\text { activity }\end{array}$ & $\begin{array}{l}\text { Promoting } \\
\text { mobilization }\end{array}$ & $\begin{array}{l}\text { Promoting } \\
\text { network } \\
\text { stability }\end{array}$ & $\begin{array}{l}\text { Ensuring } \\
\text { knowledge } \\
\text { mobility }\end{array}$ & $\begin{array}{l}\text { Ensuring } \\
\text { innovation } \\
\text { appropriability }\end{array}$ & Setting agenda & Coordinating \\
\hline Capabilities & $\begin{array}{l}\text { relationship } \\
\text { initiation } \\
\text { capability } \\
\text { (Mitrega et al., } \\
\text { 2012); } \\
\text { dual } \\
\text { capabilities, } \\
\text { i.e., capability } \\
\text { to influence } \\
\text { various } \\
\text { stakeholders } \\
\text { (Chen et al., } \\
\text { 2015); } \\
\text { alliance } \\
\text { management } \\
\text { capability } \\
\text { (Kazadi et al., } \\
\text { 2016; } \\
\text { Leischnig et } \\
\text { al., 2014); } \\
\text { Stakeholder } \\
\text { competence } \\
\text { mapping } \\
\text { capability } \\
\text { (Kazadi et al., } \\
\text { 2016) }\end{array}$ & $\begin{array}{l}\text { relationship } \\
\text { development } \\
\text { capability } \\
\text { (Mitrega et al., } \\
\text { 2012); } \\
\text { relational } \\
\text { capabilities } \\
\text { (Walter et al., } \\
\text { 2006; Dyer and } \\
\text { Singh, 1998; } \\
\text { Czakon and } \\
\text { Klimas, 2014); } \\
\text { relationship } \\
\text { termination } \\
\text { capabilities } \\
\text { (Mitrega et al., } \\
\text { 2012; Ritter } \\
\text { and Geersbro, } \\
\text { 2011); } \\
\text { supplier } \\
\text { integration } \\
\text { capability } \\
\text { (Vanpoucke et } \\
\text { al., 2014) }\end{array}$ & $\begin{array}{l}\text { knowledge } \\
\text { processing } \\
\text { capabilities } \\
\text { (e.g., Corsaro, } \\
\text { Cantù \& } \\
\text { Tunisi, 2012; } \\
\text { Helfat et al., } \\
\text { 2007); } \\
\text { communication } \\
\text { capabilities } \\
\text { (Walter et al., } \\
\text { 2006; Reinartz } \\
\text { et al., 2004); } \\
\text { Market sensing } \\
\text { capability } \\
\text { (Kazadi et al., } \\
\text { 2016); } \\
\text { stakeholder } \\
\text { knowledge } \\
\text { management } \\
\text { capability } \\
\text { (Kazadi et al., } \\
\text { 2016) }\end{array}$ & $\begin{array}{l}\text { knowledge } \\
\text { protection } \\
\text { capabilities } \\
\text { (Belderbos et } \\
\text { al., 2014; Lee } \\
\text { et al., 2007); } \\
\text { co-creation } \\
\text { capabilities } \\
\text { (Kazadi et al., } \\
\text { 2016) }\end{array}$ & $\begin{array}{l}\text { dual } \\
\text { capabilities; } \\
\text { i.e., capability } \\
\text { to influence } \\
\text { various } \\
\text { stakeholders } \\
\text { (Chen et al., } \\
\text { 2015); } \\
\text { co-creation } \\
\text { capabilities } \\
\text { (Kazadi et al., } \\
\text { 2016) }\end{array}$ & $\begin{array}{l}\text { coordination } \\
\text { capabilities } \\
\text { (Walter et al., } \\
\text { 2006); } \\
\text { relational } \\
\text { capabilities } \\
\text { (Walter et al., } \\
\text { 2006); } \\
\text { stakeholder } \\
\text { integration } \\
\text { capability } \\
\text { (Kazadi et al., } \\
\text { 2016; Driessen } \\
\text { et al., 2013); } \\
\text { supplier } \\
\text { integration } \\
\text { capability } \\
\text { (Vanpoucke et } \\
\text { al., 2014) }\end{array}$ \\
\hline
\end{tabular}

Note: This mapping is not meant to be exhaustive. 
Table 4. Role-augmentation capabilities.

\begin{tabular}{|c|c|c|}
\hline \multicolumn{3}{|c|}{$\begin{array}{l}\text { Role-augmentation capabilities } \\
\text { - Orchestrator needs to change itself, and/or develop or acquire new set of capabilities, and extend its natural } \\
\text { role-base for addressing essentially new situations. } \\
\text { - Role-augmentation capabilities shift the relationship between orchestrator type and roles. } \\
\text { - With the help of these capabilities the orchestrators can overcome the initial restrictions or orchestration } \\
\text { tvpe. }\end{array}$} \\
\hline $\begin{array}{l}\text { Re-positioning capabilities: } \\
\text { Altering relational position or } \\
\text { showing different emphases in } \\
\text { goals. }\end{array}$ & $\begin{array}{l}\text { Persuasion capabilities: } \\
\text { Showing different emphases in } \\
\text { goals; changing the way in which } \\
\text { other network members perceive } \\
\text { the orchestrator. }\end{array}$ & $\begin{array}{l}\text { Leadership-sharing capabilities: } \\
\text { Augmenting the resource base or } \\
\text { changing relational position. }\end{array}$ \\
\hline $\begin{array}{l}\text { Vodafone initially strived for } \\
\text { increasing knowledge sharing with } \\
\text { relatively traditional means: } \\
\text { "group NDA was signed to enable } \\
\text { sharing of confidential information } \\
\text { in the network." Therefore, a role } \\
\text { of a judge could be considered to } \\
\text { describe the original setting. } \\
\text { Later, in order to facilitate } \\
\text { interaction (especially sharing of } \\
\text { codified knowledge), a common } \\
\text { web portal was established. There } \\
\text { was no "centralized control" for } \\
\text { the portal, and the tool was widely } \\
\text { accessible for workers in } \\
\text { cooperating companies. "The } \\
\text { network was self-governing to } \\
\text { assure relevant inputs and } \\
\text { inclusion in execution. The } \\
\text { network orchestrator upheld the } \\
\text { view that the emergent informal } \\
\text { structure would remain non- } \\
\text { hierarchical in operation. This was } \\
\text { seen as contributing to successful } \\
\text { economic performance of the } \\
\text { network. Although a formal } \\
\text { governance structure supply chain } \\
\text { management (SCM) council, and } \\
\text { IT and Technology Management } \\
\text { (ITTM) council was subsequently } \\
\text { introduced, this did not intervene } \\
\text { with the informal functioning of } \\
\text { the virtual organization." } \\
\text { Interorganizational boundary } \\
\text { crossing activities were } \\
\text { encouraged and realized by strong } \\
\text { individuals who were able to get } \\
\text { acceptance to new ideas from all } \\
\text { the organizations involved. } \\
\text { Therefore, the influence of these } \\
\text { individuals could be considered to } \\
\text { have opened the door to developer } \\
\text { and promoter roles } \\
\text { (Saka-Helmhout \& Ibbott, } 2014, \\
\text { 134; } 135 ; 143 \text { ). }\end{array}$ & $\begin{array}{l}\text { Mobile Monday community and } \\
\text { its coordinators have pursued to } \\
\text { enhance the perception of the } \\
\text { orchestrator by promoting more } \\
\text { explicit, individually oriented } \\
\text { goals: While the network } \\
\text { leadership can be characterized as } \\
\text { facilitator-orchestrator with } \\
\text { promoter and leader roles, also } \\
\text { more concrete steps (and roles } \\
\text { such as liaison and coordinator) } \\
\text { can be considered achievable. } \\
\text { Chapter leaders' comments refer } \\
\text { to this: "I would like to see } \\
\text { cooperation in the international } \\
\text { level on very specific projects, I } \\
\text { think that it is something that was } \\
\text { probably lacking in the past... If } \\
\text { we want to bring MoMo to a } \\
\text { different level, we need to have } \\
\text { meaningful projects that again } \\
\text { people feel 'I want to be part of } \\
\text { that'. Let's say they want to } \\
\text { change how people do commerce } \\
\text { in Africa... We need projects } \\
\text { where people can collaborate and } \\
\text { also feel that they get rewards." } \\
\text { "InfoDev and the volunteer } \\
\text { networking organization Mobile } \\
\text { Monday have launched new social } \\
\text { networking hubs in Uganda and } \\
\text { Kenya [...] Supported by the } \\
\text { Government of Finland and } \\
\text { handset manufacture Nokia, this } \\
\text { project harnesses social } \\
\text { networking for innovation in } \\
\text { mobile applications" } \\
\text { (Hurmelinna-Laukkanen and } \\
\text { Nätti, 2012, 255; news, } 8 \text { March, } \\
2010, \text { Kampala, Uganda). }\end{array}$ & $\begin{array}{l}\text { "IMEC can be seen to have } \\
\text { initially assumed the roles of } \\
\text { developer and coordinator. } \\
\text { However, IMEC also 'is } \\
\text { convinced that their IAP model } \\
\text { can be leveraged into life sciences. } \\
\text { [...] nano-elentronics - the } \\
\text { expertise of IMEC - will be } \\
\text { combined with expertise in life } \\
\text { sciences. IMEC therefore will } \\
\text { team up with another orchestrator } \\
\text { that has strong competences in life } \\
\text { sciences to create a dual-core, } \\
\text { dual-site innovation ecosystem } \\
\text { where two innovation ecosystems } \\
\text { are integrated-' This allows IMEC } \\
\text { to gain access to wider set of } \\
\text { resources and benefit its network, } \\
\text { and it can take, for example, the } \\
\text { role of promoter, on one hand, or } \\
\text { the role of architect, on the other" } \\
\text { (Leten et al., 2013, 60). }\end{array}$ \\
\hline
\end{tabular}




\footnotetext{
${ }^{1}$ Examples include the Academy of Management Journal, the Academy of Management Review, Industrial Marketing and Management, the Strategic Management Journal, the Journal of Business Research, Organization Studies, the Journal of Product Innovation Management, Research Policy, Industrial and Corporate Change. ${ }^{2}$ Consider, e.g., the Good African Company, which started as a marketing company for coffee in Uganda, but from the start built its activity on the idea of supporting the rural community and coffee producers through training, investment and financing in networked form. It produces welfare like a sponsor-orchestrator, but also exhibits player-features (See 'The Entrepreneurial Spirit and the Rural Worker' available at: http://www.wipo.int/ipadvantage/en/details.jsp?id=2914 (referred to 28 Jan 2015)).

${ }^{3}$ We link role-implementation capabilities to operational capabilities even if carrying out orchestration activities inherently incorporates some dynamism and change (consider, e.g., networking capabilities introduced by Mitrega et al., [2012] that involved the whole set of capabilities from relationship initiating to termination). This is because we see managing such changes in the network as normal practices. Only when the changes are so notable that the orchestration focus needs to change are different types of capabilities introduced.

${ }^{4}$ For example, for Kazadi et al. (2016, 531), "networking capability is a firm's ability to attract, interact and communicate with certain stakeholders to consider engaging in an innovation project with the lead firm." Walter et al. $(2006,541)$ define network capability "as a firm's ability to develop and utilize inter-organizational relationships."

${ }^{5}$ In particular, we advance the discussion described in Nyström et al. (2014): they note that the role theory traditionally takes individuals as the unit of analysis, and that the industrial networks approach deviates from this by considering these aspects at the organizational level. We augment these views by considering orchestrators as the central actors.

6 "The activities of PEACRITT in an OPTIre'seaux program involve individual elements (diagnostics of the project for each involved enterprise, technical assistance, training in the enterprise, engineering) and collective elements (connecting the enterprises in the OPTIre'seaux network). PEACRITT is a non-profit organization which relies completely on public funding, mainly from the regional and national governments. Members pay a small contribution" (Batterink et al., 2010, 76).
} 